\title{
Genetic diversity of urinary bladder cancer and the risk of recurrence based on mutation analysis
}

\author{
M. TRACZYK-BORSZYNSKA ${ }^{1, *}$, E. BORKOWSKA ${ }^{1}$, Z. JABLONOWSKI ${ }^{2}$, A. JEDRZEJCZYK ${ }^{1,3}$, M. PIETRUSINSKI $^{1}$, B. KALUZEWSKI ${ }^{1,4}$, M. SOSNOWSKI $^{2}$, \\ M. BOROWIEC ${ }^{1}$ \\ ${ }^{1}$ Department of Clinical Genetics, Medical University of Lodz, Lodz, Poland; ${ }^{2} 1$ st Department of Urology, Medical University of Lodz, Lodz, \\ Poland; 'Division of Urology, John Paul II Memorial Regional Hospital, Belchatow, Poland; “"GENOS” Non-Public Healthcare Institution, Lodz, \\ Poland
}

${ }^{*}$ Correspondence: magdalena.traczyk-borszynska@umed.lodz.pl

Received March 16, 2016 / Accepted June 17, 2016

\begin{abstract}
The aim of the study was to assess the genetic diversity of bladder cancer and determine the suitability of a proposed molecular marker panel to monitor the course of bladder cancer patients. The study involved 185 patients with diagnosed bladder cancer. The genetic diversity of the bladder cancer was evaluated by the prevalence of mutations in the TP53, HRAS, FGFR3 and WWOX genes.

Mutations were detected in $62.2 \%$ of the tumor samples. The most frequently mutated genes were FGFR3 (49.7\%) and TP53 (16.2\%). No mutation was observed in the WWOX gene. FGFR3 mutations, contrary to TP53, correlated with lower tumor stage and grade, and the presence of multiple tumors. The risk of death was significantly higher in patients with TP53 mutant tumors $(\mathrm{HR}=3.12$; 95\%CI: 1.14-7.27; $\mathrm{p}=0.006)$ but lower in patients with FGFR3 mutations (HR=0.36; 95\%CI: 0.15$0.87 ; \mathrm{p}=0.002)$. None of the investigated genes was an independent predictor of disease-specific survival, recurrence-free survival or progression-free survival.

The results confirm the existence of two alternative pathways of bladder cancer. However the presence of a high percentage of wild type variants in the higher stages of the disease suggest the existence of another pathway of molecular changes leading to the development of bladder cancer. Molecular analysis may have prognostic value and may facilitate the assignment of patients to appropriate forms of treatment - especially in the case of patients with a T1 tumor, where different mutational patterns were observed in each grade.
\end{abstract}

Key words: fibroblast growth factor 3, mutation, tumor suppressor protein p53, urinary bladder, urinary bladder neoplasms

The serious medical and social problem presented by bladder cancer (BC) is demonstrated by the unfavorable epidemiological data concerning its incidence and mortality. It is the second most common cancer of the urinary tract in men worldwide [1]. Although women are affected 3-4 times less than men, more frequently advanced lesions are observed at the time of diagnosis among this group, resulting in worse effects of treatment [2]. Apart from gender, the main risk factors include smoking, occupational exposure to chemical carcinogens (mainly benzene derivatives and arylamines) and an age at diagnosis of more than 60 years [3].

Abbreviations: BC - bladder cancer; UCC - urothelial cell carcinoma
Over $90 \%$ of BC cases are urothelial cell carcinoma (UCC) [4]. It is characterized by a high heterogeneity, which may suggest that a variety of molecular changes underlie the development of this disease. Previous studies confirm the existence of two different phenotypes of UCC $[4,5]$. Most UCCs belong to a low-grade non-muscle-invasive disease, characterized by FGFR3 mutations, loss of chromosome 9, and an indolent clinical phenotype [6]. High-grade muscle-invasive carcinoma demonstrates numerous genetic and epigenetic alterations, such as loss of TP53 function, which is associated with the high genetic instability of these tumors, and worse prognosis [4-6].

Although the value of genetic markers in the early diagnosis, prognosis and monitoring of UCC remains still rather limited, 
the understanding of the relationship between molecular findings and clinical outcomes is growing. However, it is important to choose appropriate molecular markers for any such analysis. In the case of UCC, research has focused on markers that might predict tumor recurrence, help identify patients in need of early and aggressive treatment, or might allow the most effective therapy to be to selected. The aim of our study was to determine the genetic diversity of bladder cancer based on molecular analysis of the FGFR3, TP53, HRAS and WWOX genes, and to determine the value of a proposed molecular marker panel to monitor the course of bladder cancer patients. Examined genes were selected based on previously published data $[4,5,7,8]$.

\section{Materials and methods}

The study included patients hospitalized at one of three Urology Departments in the Lodz region (Poland) during the period 2005 to 2012 with a suspicion of BC. The male/female ratio was 3:1, median age 68 years. Samples were obtained from urinary bladder by transurethral resection and evaluated by the trained pathologists to determine the presence of UCC, its grade and the invasion depth. Parallel sets of clinical data from patients were assembled. The study was approved by the Ethics Committee of the Medical University of Lodz (permission No: RNN/215/10/KE).

DNA examination. For the purposes of the study, samples of tumor tissue were taken from patients with suspicion of BC. The removed tumors were frozen in liquid nitrogen and stored at $-70^{\circ} \mathrm{C}$ until DNA isolation. After histopathological examination, 185 samples of tumor tissue (UCC) were enrolled to the study. The DNA isolation steps were carried out according to the manufacturer's protocol (Sherlock AX; A\&A Biotechnology, Poland). The isolated DNA was stored at $4-8^{\circ} \mathrm{C}$.

Mutation analysis of the FGFR3 (exons 7, 10, 15), TP53 (exons 4-8), HRAS (exons 1-2) and WWOX (exon 6) genes was carried out using multi-temperature single strand conformational polymorphism (MSSCP) analysis and confirmed by sequencing, as detailed previously $[9,10,11]$.

Characterization of study subjects. Complete clinical data was collected from 163 patients (88.1\%). During follow-up (average 18.4 months), recurrence was noted in 101 patients (61.9\%), of which 36 cases of disease progression were observed $(22.1 \%)$. Death from BC was recorded in 26 cases (14\%). The characteristics of the study group are shown in Table 1.

Statistical analysis. The statistical analyses were performed using STATISTICA 10 (StatSoft, Inc., Tulsa, OK, USA). In all conducted analyses, P-values less than 0.05 were reported as statistically significant. Categorical variables were compered by the $\chi^{2}$ and Fisher's exact tests, the Kaplan-Meier method and log-rank test. Disease-specific survival was calculated from the time of enrollment into the study until the date of death due to BC. Event-free survival was calculated from the date of removal of the tumor until the date of disease relapse, progression or the date of the last visit. Recurrence was classified when the second UCC was of a better or similar stage/grade, and progression was associated with a more advanced stage/grade. The factors found to be statistically significant in univariate analyses were entered into the Cox model to determine the independent prognostic factors.

\section{Results}

Mutations frequency. Bladder cancer patients underwent molecular analysis of the FGFR3, TP53, HRAS and WWOX genes. In total, $62.2 \%(115 / 185)$ of all tumors were identified on the basis of these. Overall, $13.0 \%$ of samples (24/185) showed mutations in more than one testing gene. Among 144 detected mutations, $71.5 \%$ were localized in the FGFR3

Table 1. Clinicopathological characterization of 185 patients with diagnosed UCC.

\begin{tabular}{|c|c|c|c|}
\hline $\begin{array}{l}\text { Clinopathological } \\
\text { parameters }\end{array}$ & Categorization & $\begin{array}{c}\text { Number of patients } \\
n=185\end{array}$ & $\begin{array}{c}\text { Frequency } \\
{[\%]}\end{array}$ \\
\hline & Primary tumour & 121 & $65.4 \%$ \\
\hline & Recurrent disease & 64 & $34.6 \%$ \\
\hline \multicolumn{4}{|l|}{ Sex } \\
\hline & Female & 35 & $18.9 \%$ \\
\hline & Male & 150 & $81.1 \%$ \\
\hline \multicolumn{4}{|l|}{ Age at diagnosis } \\
\hline & $<60$ years & 50 & $27.0 \%$ \\
\hline & $\geq 60$ years & 135 & $73.0 \%$ \\
\hline \multicolumn{4}{|l|}{ Smoking status } \\
\hline & Yes & 153 & $82.7 \%$ \\
\hline & No & 32 & $17.3 \%$ \\
\hline \multicolumn{4}{|l|}{$\begin{array}{l}\text { Occupational } \\
\text { exposure }\end{array}$} \\
\hline & Yes & 89 & $48.1 \%$ \\
\hline & No & 96 & $51.9 \%$ \\
\hline \multicolumn{4}{|l|}{ Tumor stage } \\
\hline & $\mathrm{Ta}$ & 106 & $57.3 \%$ \\
\hline & $\mathrm{T} 1$ & 56 & $30.3 \%$ \\
\hline & $\mathrm{T} 2$ & 18 & $9.7 \%$ \\
\hline & $\mathrm{T} 3$ & 4 & $2.2 \%$ \\
\hline & $\mathrm{T} 4$ & 1 & $0.5 \%$ \\
\hline \multicolumn{4}{|l|}{ Tumor grade } \\
\hline & G1 & 102 & $55.1 \%$ \\
\hline & G2 & 54 & $29.2 \%$ \\
\hline & G3 & 29 & $15.7 \%$ \\
\hline \multicolumn{4}{|l|}{ Tumor size } \\
\hline & $<3 \mathrm{~cm}$ & 101 & $54.6 \%$ \\
\hline & $\geq 3 \mathrm{~cm}$ & 84 & $45.4 \%$ \\
\hline \multicolumn{4}{|l|}{ Multiplicity } \\
\hline & Solitary & 116 & $62.7 \%$ \\
\hline & Multiple & 69 & $37.3 \%$ \\
\hline
\end{tabular}


gene, $26.4 \%$ in the TP53 gene and $2.1 \%$ in the HRAS gene. None of the bladder tumors showed any WWOX alterations. All the detected mutations were point mutations: 142 missense mutations, one nonsense mutation and one frameshift mutation.

MSSCP analysis and DNA sequencing revealed changes in FGFR3 in $49.7 \%$ (92/185) of cases. The most frequent FGFR3 mutations were S249C (51.1\%) and Y375C (39.1\%). In the TP53 gene, mutations were observed in $16.2 \%(30 / 185)$ of cases, out of which $53.3 \%$ were detected in exon $8,26.7 \%$ in exon $7,13.3 \%$ in exon 5 and $6.7 \%$ in exon 6 . Only three mutations were observed in the HRAS gene (Q61L). Due to the low prevalence of mutations found in this gene, they were excluded from further statistical analysis.

Association between FGFR3 and TP53 mutations and clinicopathological parameters. The relationship between the results of molecular analysis and clinical and histopathological characteristics are shown in Table 2. There was no significant association between mutational status of FGFR3 gene and sex $(\mathrm{p}=0.820)$, age $(\mathrm{p}=0.710)$, smoking status ( $\mathrm{p}=0.720)$, occupational exposure $(\mathrm{p}=0.610)$ or tumor size $(\mathrm{p}=0.090)$. FGFR3 mutations were more frequent in $\mathrm{Ta}$ stage tumors $(60.4 \% ; \mathrm{p}<0.001)$, well-differentiated tumors (60.8\%; $\mathrm{p}<0.001)$ and multiple tumors (60.9\%; $\mathrm{p}=0.020)$. Also, statistically significant relationships were found between the occurrence of the TP53 mutation and tumor stage $(\mathrm{p}=0.040)$ and grade $(\mathrm{p}=0.003)$. Mutations in this gene were more frequent in the higher stages of disease $(22.8 \%)$, and in G2 (20.4\%) and G3 (34.5\%) tumors. TP53 mutations were not associated with sex $(p=0.870)$, age $(p=0.340)$, smoking status $(\mathrm{p}=0.67)$, occupational exposure $(\mathrm{p}=0.330)$, tumor multiplicity $(0.080)$ or size $(\mathrm{p}=0.880)$.

The analysis of the relationship between the coexistence of FGFR3 and TP53 mutations and clinicopathological parameters in BC patients was based on four genotypes: FGFR3WT/TP53WT, FGFR3Mut/TP53WT, FGFR3WT/ TP53Mut and FGFR3Mut/TP53Mut. A strong correlation was found between the existence of mutations in the examined genes and tumor stage $(\mathrm{p}=0.002)$ and grade $(\mathrm{p}=0.001)$. No correlation was observed between each genotype and

Table 2. Frequency of FGFR3 and TP53 mutations in BC patients compared with clinicopathological parameters.

\begin{tabular}{|c|c|c|c|c|c|c|c|}
\hline \multirow{2}{*}{ Clinopathological parameters } & \multirow{2}{*}{ Categorization } & \multicolumn{2}{|c|}{ FGFR3 } & \multirow{2}{*}{$\mathbf{p}$} & \multicolumn{2}{|c|}{ TP53 } & \multirow{2}{*}{$\mathbf{p}$} \\
\hline & & WT & Mut (\%) & & WT & Mut (\%) & \\
\hline \multicolumn{8}{|l|}{ Sex } \\
\hline & Female & 17 & $18(51.4 \%)$ & 0.820 & 29 & $6(17.1 \%)$ & 0.870 \\
\hline & Male & 76 & $74(47.9 \%)$ & & 126 & $24(16.0 \%)$ & \\
\hline \multicolumn{8}{|l|}{ Age at diagnosis } \\
\hline & $<60$ years & 24 & $26(52.0 \%)$ & 0.710 & 44 & $6(12.0 \%)$ & 0.340 \\
\hline & $\geq 60$ years & 69 & $66(48.9 \%)$ & & 111 & $24(17.8 \%)$ & \\
\hline \multicolumn{8}{|l|}{ Smoking status } \\
\hline & Yes & 76 & $77(50.3 \%)$ & 0.720 & 129 & $24(15.7 \%)$ & 0.670 \\
\hline & No & 17 & $15(46.9 \%)$ & & 26 & $6(18.8 \%)$ & \\
\hline \multicolumn{8}{|l|}{ Occupational exposure } \\
\hline & Yes & 43 & $46(51.7 \%)$ & 0.610 & 77 & $12(13.5 \%)$ & 0.330 \\
\hline & No & 50 & $46(47.9 \%)$ & & 78 & $18(18.8 \%)$ & \\
\hline \multicolumn{8}{|l|}{ Tumor stage } \\
\hline & $\mathrm{Ta}$ & 42 & $64(60.4 \%)$ & $<0.001^{\star}$ & 94 & $12(11.3 \%)$ & $0.040^{*}$ \\
\hline & $>\mathrm{Ta}$ & 51 & $28(35.4 \%)$ & & 61 & $18(22.8 \%)$ & \\
\hline \multicolumn{8}{|l|}{ Tumor grade } \\
\hline & G1 & 40 & $62(60.8 \%)$ & $<0.001^{\star}$ & 93 & $9(8.8 \%)$ & $0.003^{*}$ \\
\hline & G2 & 29 & $25(46.3 \%)$ & & 43 & $11(20.4 \%)$ & \\
\hline & G3 & 24 & $5(17.2 \%)$ & & 19 & $10(34.5 \%)$ & \\
\hline \multicolumn{8}{|l|}{ Multiplicity } \\
\hline & Solitary & 66 & $50(43.1 \%)$ & $0.020^{*}$ & 93 & $23(19.8 \%)$ & 0.080 \\
\hline & Multiple & 27 & $42(60.9 \%)$ & & 62 & $7(10.1 \%)$ & \\
\hline \multicolumn{8}{|l|}{ Tumor size } \\
\hline & $<3 \mathrm{~cm}$ & 45 & $56(55.4 \%)$ & 0.090 & 85 & $16(15.8 \%)$ & 0.880 \\
\hline & $\geq 3 \mathrm{~cm}$ & 48 & $36(42.9 \%)$ & & 70 & $14(16.7 \%)$ & \\
\hline
\end{tabular}

* bold face representing $\mathrm{p}$-values $<0.05$

Mut - mutation; WT - wild type 
A

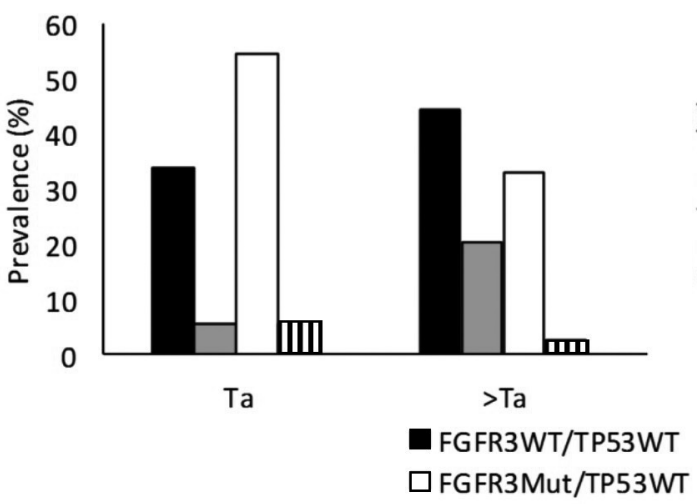

B

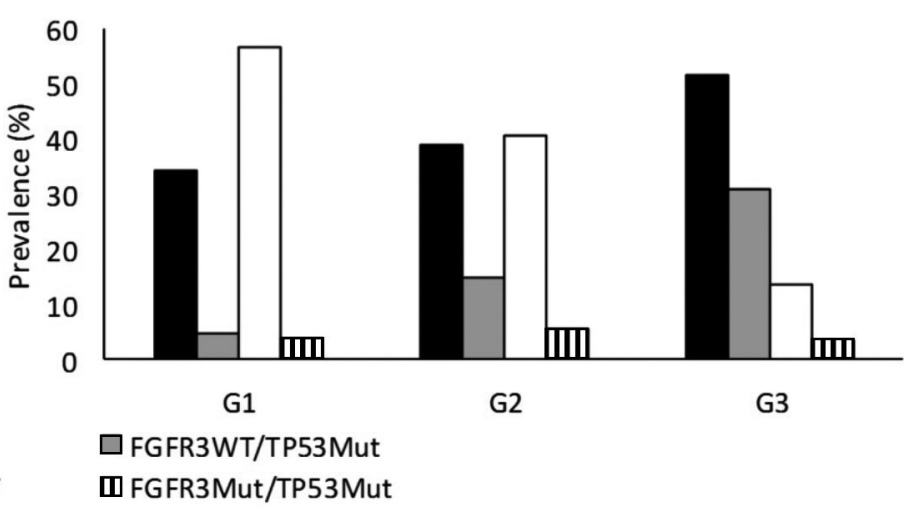

Figure 1. A comparison of the prevalence of different mutational patterns regarding (A) tumor stage and (B) grade in $\mathrm{BC}$ patients. Mut - mutation; WT - wild type

sex $(p=0.970)$, age $(p=0.490)$, smoking status $(p=0.900)$, occupational exposure $(\mathrm{p}=0.770)$, multiplicity $(\mathrm{p}=0.070)$ or tumor size $(\mathrm{p}=0.400)$.

The FGFR3Mut/TP53WT mutational pattern dominated in both Ta and G1 tumors (54.7\% and 56.9\% respectively), while the percentages of FGFR3WT/TP53Mut and FGFR3Mut/TP53Mut genotypes varied from $3.9 \%$ to $5.7 \%$. In the case of more advanced lesions, the percentage of FGFR3WT/TP53Mut tumors prevailed over FGFR3Mut/ TP53WT tumors (Figure 1A, B). In these groups of tumors, a high prevalence of the FGFR3WT/TP53WT genotype was also observed $(44.3 \%$ and $51.7 \%$ for tumors $>\mathrm{Ta}$ and G3 respectively).

An analysis of the FGFR3 and TP53 mutations based on combined stage and grade (Figure 2) indicated that FGFR3Mut/TP53WT was the most prevalent genotype in the TaG1-2 and $\mathrm{T} 1 \mathrm{G} 1-2$ tumors ( $54.7 \%$ and $46.5 \%$ respectively), whereas in T1G3 tumors, the FGFR3Mut/TP53WT variant was more common than the FGFR3WT/TP53Mut genotype (38.5\% vs. $15.4 \%)$. In the more advanced lesions, the most common genotype was FGFR3WT/TP53WT (60.9\%). These results were also statistically significant $(\mathrm{p}=0.006)$.

Prognostic value of FGFR3 and TP53 mutations and their association with clinicopathological characteristics and patient outcome. The presence of a TP53 mutation was found to be an unfavorable prognostic factor for diseasespecific survival $(p=0.016)$ (Figure $3 \mathrm{~A})$. Patients with a mutation in this gene had more than three times higher risk of death $(\mathrm{HR}=3.12 ; 95 \% \mathrm{CI}: 1.14-7.27 ; \mathrm{p}=0.006)$. Contrary to TP53 mutations, alterations in FGFR3 were connected with higher disease-specific survival $(\mathrm{p}=0.003)$ (Figure $3 \mathrm{~B})$. In this case, the risk of death was $\mathrm{HR}=0.36$ (95\%CI: $0.15-0.87 ; \mathrm{p}=0.002)$. The 5-year survival rate was higher in patients with an FGFR3 mutation than those with TP53 alterations ( $85.5 \%$ vs. $66.6 \%$ ). No statistically significant differences were found between the occurrence of mutations

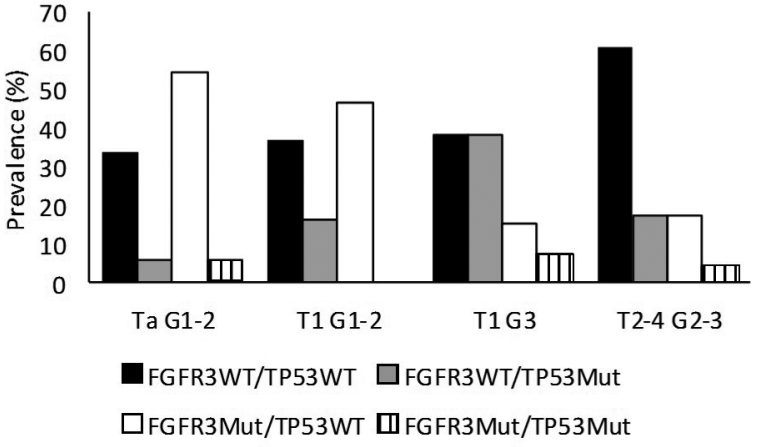

Figure 2. A comparison of the prevalence of different mutational patterns regarding tumor histopathological parameters in $\mathrm{BC}$ patients. Mut - mutation; WT- wild type.

in the examined genes, and recurrence-free survival and progression-free survival.

The Kaplan-Meier analysis for disease-specific survival with regard to four combinations of FGFR3/TP53 Mut/ WT genotypes revealed that patients with the FGFR3Mut/ TP53Mut variant had significantly higher survival rates then FGFR3WT/TP53Mut patients $(\mathrm{p}<0.001)$ (Figure 3C). No significant differences were observed for recurrence-free survival rate or progression-free survival rate regardless of mutational pattern of the FGFR3/TP53 genes.

Univariate analysis identified histopathological criteria, tumor size, age at diagnosis and occurrence of mutations in FGFR3 and TP53 genes as factors associated with BC outcomes. Since these parameters are not necessarily independent, multivariate analysis was used to determine the impact of each factor. None of the investigated genes was an independent prognostic factor for disease-specific survival, recurrence-free survival or progression-free survival (Table 3). Multivariate Cox regression analysis showed that for disease- 

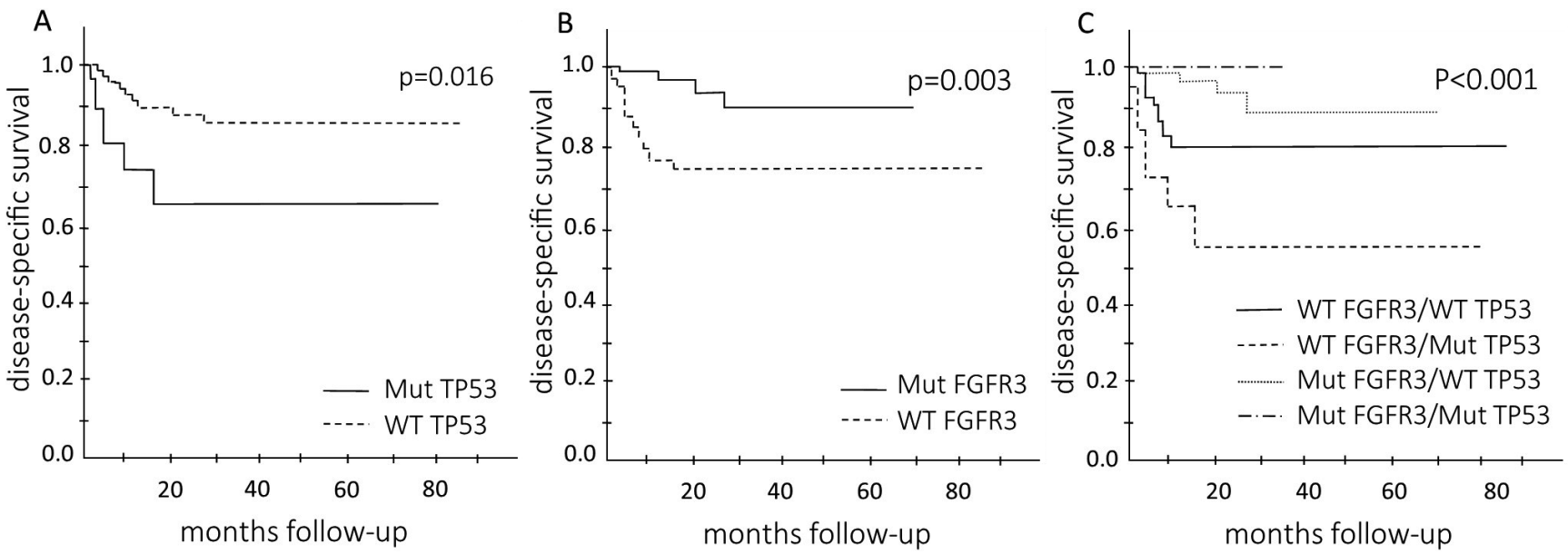

Figure 3. Kaplan-Meier plots for disease-specific survival in relation to (A) TP53 and (B) FGFR3 mutations and (C) four combinations of genotypes. (A) Mutations in TP53 gene were significantly associated with poor prognosis (p $[\log -\operatorname{rank}]=0.016)$ as opposed to (B) FGFR3 mutations, which significantly correlated with longer survival (p[log-rank] $=0.003)$ in BC patients $(n=185)$. (C) Good prognosis was also associated with the genotype FGFR3Mut/TP53Mut (p[log-rank]<0.001). A dashed vertical line on survival curves mark censored cases; circle-indicate uncensored cases. Mut - mutation; WT - wild type.

specific survival, the only independent prognostic factor was a tumor size more than $3 \mathrm{~cm}(\mathrm{HR}=6.53$; 95\%CI: 1.46-29.18; $\mathrm{p}=0.014)$. Grade $\mathrm{G} 3$ turned out to be a negative prognostic factor for recurrence-free survival ( $\mathrm{HR}=3.08$; 95\%CI: 1.40 $6.80 ; \mathrm{p}=0.005)$. Statistically significant variables predicting progression-free survival were stage $>\mathrm{Ta}(\mathrm{HR}=2.82$; 95\%CI: 1.07-7.42; $\mathrm{p}=0.040)$ and $\mathrm{G} 3$ grade $(\mathrm{HR}=3.64 ; 95 \% \mathrm{CI}$ : 1.13 $11.78 ; \mathrm{p}=0.030)$.

\section{Discussion}

By analyzing the mutational status of TP53, HRAS, FGFR3 and WWOX genes, it was possible to identify $62.2 \%$ of all examined tumors. Bladder cancer development is clearly associated with the mutations in the FGFR3 and TP53 genes $[4,12]$. Our observations indicate that FGFR3 mutations are characteristic of multiple, well-differentiated Ta tumors, whereas TP53 mutations are more common in clinically and histologically-advanced disease. In addition, our results confirm that TP53 mutations are an unfavorable prognostic factor. Alterations in this gene are associated with poor differentiation, advanced UCC and poor prognosis $[12,13]$. Contrary to our present study, previous conclusions concerning the link between TP53 mutational status and prognosis were drawn mostly based on the expression of nuclear p53 protein as a surrogate marker of mutations [12, 14, 15]. However, p53 nuclear overexpression is not always caused by mutations $[13,15]$, it may also be the result of physiological processes occurring in response to DNA damage. Hence, other studies demonstrate many discrepancies based on the method of analysis of TP53 as a prognostic marker in BC patients, as well as differences in the composition of the study group [16]. The greatest differences concern recurrence, insofar that while our studies indicate that TP53 mutations are not associated with the recurrence of BC, Shariat et al. [17] claim the opposite. It remains unclear whether changes in TP53 act as markers of outcome in patients with BC [15].

The results of our research show that patients with mutations in both FGFR3 and TP53 genes have significantly longer overall survival than patients with the FGFR3WT/ TP53Mut genotype. This confirms that FGFR3 and TP53 mutations stimulate the development of distinct types of BC. Mutations in the FGFR3 gene are being considered as surrogate markers for the detection of genome stable bladder tumors [18]. Mutations in this gene correlate with a low frequency of chromosome alterations, which explains its "protective effect" on patient survival, the fact that these alterations are characteristic for tumors in the Ta stage, and are associated with good prognosis [19]. However, as bladder cancer development is a complex process which is not clearly understood, evaluation of FGFR3 mutational status is not a sufficient prognostic marker: The study of single determinants does not accurately reflect the cascade of molecular aberrations. Ploussard et al. found that the prognostic value of FGFR3 mutational status for disease recurrence and progression depends on allelic losses at 9p22 [20]. Likewise, Rebouissou et al. suggest that the homozygous deletion of CDKN2A (9p21) leads to the progression of FGFR3Mut non-muscle-invasive disease [21]. However, van Rhijn et al. showed that the combination of FGFR3 with MIB-1 (Ki67) seemed to confer a more accurate prediction of progression and disease-specific survival than each of these markers alone [22]. 
The molecular diversity of bladder cancer is even more apparent when analyzing the frequencies of four different genotypes, FGFR3WT/TP53WT, FGFR3Mut/TP53WT, FGFR3WT/TP53Mut and FGFR3Mut/TP53Mut, with regard to tumor stage and grade. A high percentage of FGFR3Mut/ TP53WT genotypes were observed in Ta and G1 tumors, while FGFR3WT/TP53Mut variants were more common in higher stages/grades of tumors, which is consistent with previous studies $[23,24]$. The combination of the $\mathrm{T}$ and $\mathrm{G}$ characteristics, and the mutations in the two genes, revealed the presence of FGFR3 mutations in more than half of the Ta G1-G2 tumors. The most common variant in the advanced tumors (T2-4 G2-3) was FGFR3WT/TP53WT (60.9\%), while mutations in FGFR3 and TP53 occurred with equally low incidence (17.4\%). However, the most interesting observations concern stage T1. Tumors in T1 G1-2

Table 3. Multivariate Cox regression analysis for the prediction of disease-specific survival, recurrence and progression in $185 \mathrm{BC}$ patients. The table shows variables that were found to be significant prognostic factors for disease-specific survival, recurrence- free survival and progression - free survival (log-rank test).

\begin{tabular}{|c|c|c|c|c|c|c|c|c|}
\hline \multirow{2}{*}{ Clinopathological parameters } & \multirow{2}{*}{ Categorization } & \multirow{2}{*}{$\mathbf{p}^{\dagger}$} & \multicolumn{3}{|c|}{ Univariate } & \multicolumn{3}{|c|}{ Multivariate } \\
\hline & & & HR & 95\% CI & $\mathbf{p}^{*}$ & HR & 95\% CI & $\mathbf{p}^{*}$ \\
\hline \multicolumn{9}{|c|}{ DISEASE-SPECIFIC SURVIVAL } \\
\hline \multicolumn{9}{|l|}{ Age at diagnosis } \\
\hline & $<60$ years & $0.024^{*}$ & 1 & & $0.050^{*}$ & 1 & & 0.283 \\
\hline & $\geq 60$ years & & 4.36 & $1.02-18.76$ & & 2.32 & $0.50-10.77$ & \\
\hline \multicolumn{9}{|l|}{ Tumor stage } \\
\hline & $\mathrm{Ta}$ & $<0.001^{*}$ & 1 & & $<0.001^{*}$ & 1 & & 0.095 \\
\hline & $>\mathrm{Ta}$ & & 16.48 & $3.82-70.97$ & & 4.66 & $0.77-28.37$ & \\
\hline \multicolumn{9}{|l|}{ Tumor grade } \\
\hline & G1 & & 1 & & & 1 & & \\
\hline & G2 & $<0.001^{\star}$ & 5.52 & $1.46-20.83$ & $0.012^{*}$ & 1.95 & $0.41-9.29$ & 0.402 \\
\hline & G3 & & 26.67 & 7.19-99.01 & $<0.001^{*}$ & 3.67 & $0.69-19.53$ & 0.127 \\
\hline \multicolumn{9}{|l|}{ Tumor size } \\
\hline & $<3 \mathrm{~cm}$ & & 1 & & & 1 & & \\
\hline & $\geq 3 \mathrm{~cm}$ & $<0.001^{\star}$ & 11.32 & $2.64-48.64$ & $0.001^{\star}$ & 6.53 & $1.46-29.18$ & $0.014^{\star}$ \\
\hline \multicolumn{9}{|l|}{ FGFR3 } \\
\hline & Mut & $0.003 *$ & 1 & & & 1 & & \\
\hline & WT & $0.003^{\star}$ & 2.77 & $1.16-6.63$ & $0.002^{\star}$ & 2.73 & $0.86-8.69$ & 0.089 \\
\hline \multicolumn{9}{|l|}{ TP53 } \\
\hline & Mut & & 3.12 & $1.14-7.27$ & & 1.24 & $0.46-3.37$ & 0.670 \\
\hline & WT & $0.016^{*}$ & 1 & & $0.006^{*}$ & 1 & & \\
\hline & & RECURRE & E-FREE & RVIVAL & & & & \\
\hline \multicolumn{9}{|l|}{ Tumor stage } \\
\hline & $\mathrm{Ta}$ & $0.013^{\star}$ & 1 & & & 1 & & \\
\hline & $>\mathrm{Ta}$ & & 1.68 & $1.12-2.50$ & $0.010^{*}$ & 1.28 & $0.73-2.27$ & 0.390 \\
\hline \multicolumn{9}{|l|}{ Tumor grade } \\
\hline & G1 & $<0_{0001}^{*}$ & 1 & & & 1 & & \\
\hline & G2 & & 1.25 & $0.80-1.94$ & 0.320 & 1.07 & $0.61-1.89$ & 0.810 \\
\hline & G3 & & 3.84 & $2.07-7.12$ & $<0.001^{\star *}$ & 3.08 & $1.40-6.80$ & $0.005^{*}$ \\
\hline & & PROGRES & N-FREI & RVIVAL & & & & \\
\hline \multicolumn{9}{|l|}{ Tumor stage } \\
\hline & $\mathrm{Ta}$ & $<\mathbf{0 . 0 0 1}^{\star}$ & 1 & & & 1 & & \\
\hline & $>\mathrm{Ta}$ & & 3.89 & $1.92-7-87$ & $<0.001^{\star *}$ & 2.82 & $1.07-7.42$ & $0.040^{*}$ \\
\hline \multicolumn{9}{|l|}{ Tumor grade } \\
\hline & G1 & $<0.001^{\star *}$ & 1 & & & 1 & & \\
\hline & G2 & & 2.05 & $0.97-4.35$ & 0.061 & 1.09 & $0.42-2.83$ & 0.860 \\
\hline & G3 & & 8.52 & $3.37-21.53$ & $<0.001^{\star *}$ & 3.64 & $1.13-11.78$ & $0.030^{*}$ \\
\hline
\end{tabular}

$\dagger$ log-rank test; $¥$ Cox regression; ${ }^{*}$ bold face representing p-values $<0.05$; Mut - mutation; WT - wild type 
were characterized by high prevalence of FGFR3 mutations (46.5\%), while mutations in TP53 were more common in the T1 G3 tumors (38.5\%). The presence of two different frequencies of TP53 mutations may indicate the presence of two different molecular pathways for T1 tumor development. The molecular analysis of FGFR3 and TP53 genes in this group of BC patients may allow patients to be directed towards appropriate forms of treatment.

Our findings indicate that the prevalence of tumors with wild-type FGFR3 and TP53 genes increased with malignancy. Similar observations were reported by Neuzillet et al. [24]. This phenomenon may be explained by the high expression of cell-cycle genes for the cases with the FGFR3WT/TP53WT genotype, even more pronounced than in cases with the FGFR3WT/TP53Mut variant [25]. Also, ARID1A mutations were most frequently observed in the FGFR3WT tumors, associated with poor prognosis [26], while methylation of RASSF1A in this kind of BC correlated with higher stage and grade [27]. Furthermore, data from our previous loss of heterozygosity $(\mathrm{LOH})$ study indicates that $\mathrm{LOH}$ of the TP53, $R B 1$ and $C D K N 2 A / A R F$ genes is more often observed in $>\mathrm{Ta}$ and G3 tumors [28].

To understand how this cancer develops, it is necessary to identify other genetic markers associated with BC. Therefore, we attempted to verify whether WWOX gene mutations are linked to the development of more clinically and histopathologically advanced tumors. WWOX is one example of a tumor suppressor gene. In human tumors, WWOX is inactivated by $\mathrm{LOH}$, homozygous deletions or epigenetic methylation. Little is known about these alterations in bladder cancer, but they may possibly lead to loss of WWOX expression in higher stage and grade tumors $[7,8]$. The literature gives no reports concerning the prevalence of WWOX mutations in BC, only a few papers concerning the incidence of these gene mutations have been published regarding other neoplasms [10, 29, 30]. Unfortunately, no WWOX mutations were identified in the examined DNA samples.

Low mutation prevalence were found in HRAS gene. Previously published data showed large discrepancies in HRAS mutations occurrence in BC patients (vary between 0-30\%) [31]. Beukers et al. indicated higher number of mutations in this gene in young BC patients ( $<20$ years) compared with older age group [32]. They hypothesized that some of the younger patients might be mosaic for the HRAS germinal mutation and therefore could express some of the clinical features of Costello Syndrome, like tumor predisposition. Their results suggest that mosaicism for oncogenic HRAS mutations may increase the risk for developing $\mathrm{BC}$ at a young age.

Most molecular markers show a relation to tumor grade and stage, and may be used to predict survival, but not recurrence [16], which has been confirmed by our research. While univariate Cox regression analysis found FGFR3 and TP53 mutations to be connected with patient survival, they were not found to be independent prognostic factors in multivariate Cox regression analysis (age, stage, grade, tumor size and mutations in FGFR3 and TP53 genes). The only independent prognostic factor for disease-specific survival was tumor size greater than $3 \mathrm{~cm}$. Grade $\mathrm{G} 3$ turned out to be an independent prognostic factor for recurrence, and two factors were found to be statistically independent for progression: stage $>\mathrm{Ta}$ and grade G3.

In conclusion, the high prevalence of wild variants in $\mathrm{BC}$, particularly in the advanced form, suggests the existence of another pathway of molecular changes underlying the development of this disease. Our observations confirm the high heterogeneity of $\mathrm{BC}$, and the fact that it is impossible to find one molecular marker to predict the course of the disease. It is clearly connected with the differences in the pathways of $\mathrm{BC}$ development and progression. The molecular background of BC development should be considered with regard to aspects which are different but closely related and interdependent: chromosomal aberrations, gene mutations, abnormalities in protein functions. Only a comprehensive approach to these molecular changes can allow the design of standards for molecular diagnostics in routine clinical practice.

Acknowledgements: The reported study was carried out as part of Research Project No. 502-03/2-159-02/502-24-017 from the Medical University of Lodz. Our studies and applied procedures were approved by the Committee of Ethics at the Medical University of Lodz (Document No. RNN/215/10/KE).

GENOS Non-Public Healthcare Institution, member of Polish Technology Platform for Innovative Medicine, of the National Centre for Research and Development.

\section{References}

[1] FERLAY J, SOERJOMATARAM I, ERVIK M, DIKSHIT R, ESER S et al. GLOBOCAN 2012 v1.0, Cancer Incidence and Mortality Worldwide: IARC CancerBase No. 11 Lyon, France: International Agency for Research on Cancer; 2013. [Online]. Available: http://globocan.iarc.fr. [Accessed 26 March 2015].

[2] DOBRUCH J, DANESHMAND S, FISCH M, LOTAN Y, NOON A et al. Gender and Bladder Cancer: A Collaborative Review of Etiology, Biology, and Outcomes. Eur Urol 2016; 69: 300-310. http://dx.doi.org/10.1016/j. eururo.2015.08.037

[3] BURGER M, CATTO J, DALBAGNI G, GROSSMAN H, HERR $H$ et al. Epidemiology and risk factors of urothelial bladder cancer. Eur Urol 2013; 63: 234-241. http://dx.doi. org/10.1016/j.eururo.2012.07.033

[4] KNOWLES M, HURST C. Molecular biology of bladder cancer: new insights into pathogenesis and clinical diversity. Nat Rev Cancer 2015; 15: 25-41. http://dx.doi.org/10.1038/ nrc3817

[5] GOEBELL P, KNOWLES M. Bladder cancer or bladder cancers? Genetically distinct malignant conditions of the urothelium. Urol Oncol 2010; 28: 409-428. http://dx.doi. org/10.1016/j.urolonc.2010.04.003 
[6] CATTO J, MIAH S., OWEN H, BRYANT H, MYERS K et al. Distinct microRNA alterations characterize high - and lowgrade bladder cancer. Cancer Res 2009; 69: 8472-8481. http:// dx.doi.org/10.1158/0008-5472.CAN-09-0744

[7] ILIOPOULOS D, GULER G, HAN S, JONSTON D, DRUCK $\mathrm{T}$ et al. Fragile genes as biomarkers: epigenetic control of WWOX and FHIT in lung, breast and bladder cancer. Oncogene 2005; 24: 1625-1633. http://dx.doi.org/10.1038/ sj.onc. 1208398

[8] PŁUCIENNIK E, NOWAKOWSKA M, STEPIEN A, WOLKOWICZ M, STAWINSKI A et al. Alternating expression levels of WWOX tumor suppressor and cancer-related genes in patients with bladder cancer. Oncol Lett 2014; 8: 2291-2297. http://dx.doi.org/10.3892/ol.2014.2476

[9] BORKOWSKA E, BINKA-KOWALSKA A, CONSTANTINOU M, NAWROCKA A, MATYCH J et al. P53 mutations in urinary bladder cancer patients from Central Poland. J Appl Genet 2007; 48: 177-183. http://dx.doi.org/10.1007/ BF03194676

[10] BEDNAREK A, LAFLIN K, DANIEL R, LIAO Q, HAWKINS K et al. WWOX, a novel WW domain-containing protein mapping to human chromosome 16q23.3-24.1, a region frequently affected in breast cancer. Cancer Res 2000; 15: 2140-2145.

[11] KOMPIER L, LURKIN I, VAN DER AA M, VAN RHIJN B, VAN DER KWAST T et al. FGFR3, HRAS, KRAS, NRAS and PIK3CA Mutations in Bladder Cancer and Their Potential as Biomarkers for Surveillance and Therapy. PLoS One 2010; 5: e13821. http://dx.doi.org/10.1371/journal. pone.0013821

[12] VAN RHIJN B, VAN DER KWAST T, Vis A, KIRKELS W, BOEVE E et al. FGFR3 and P53 characterize alternative genetic pathways in the pathogenesis of urothelial cell carcinoma. Cancer Res 2004; 64: 1911-1914. http://dx.doi. org/10.1158/0008-5472.CAN-03-2421

[13] ECKE T, SACHS M, LENK S, LOENING S, SCHLECHTE H. TP53 gene mutations as an independent marker for urinary bladder cancer progression. Int J Mol Med 2008; 21: 655-661. http://dx.doi.org/10.3892/ijmm.21.5.655

[14] GOEBELL P, GROSHEN S, SCHMITZ-DRÄGER B. p53 immunohistochemistry in bladder cancer - a new approach to an old question. Urol Oncol 2010; 28: 377-388. http://dx.doi. org/10.1016/j.urolonc.2010.03.021

[15] MALATS N, BUSTOS A, NASCIMENTO C, FERNANDEZ F, RIVAS M et al. P53 as a prognostic marker for bladder cancer: a meta-analysis and review. Lancet Oncol 2005; 6: 678-686. http://dx.doi.org/10.1016/S1470-2045(05)70315-6

[16] VAN RHIJN B, CATTO J, GOEBELL P, KNUCHEL R, SHARIAT $S$ et al. Molecular markers for urothelial bladder cancer prognosis: Toward implementation in clinical practice. Urol Oncol 2014; 32: 1078-1087. http://dx.doi.org/10.1016/j. urolonc.2014.07.002

[17] SHARIAT S, ASHFAQ R, SAGALOWSKY A, LOTAN Y. Predictive value of cell cycle biomarkers in nonmuscle invasive bladder transitional cell carcinoma. J Urol 2007; 177: 481-487. http://dx.doi.org/10.1016/j.juro.2006.09.038

[18] JUNKER K, VAN OERS J, ZWARTHOFF E, KANIA I, SCHUBERT J et al. Fibroblast Growth Factor Receptor 3
Mutations in Bladder Tumors Correlate with Low Frequency of Chromosome Alterations. Neoplasia 2008; 10: 1-7. http:// dx.doi.org/10.1593/neo.07178

[19] BURGER M, VAN DER AA M, VAN OERS J, BRINKMANN A, VAN DER KWAST T et al. Prediction of progression of non-muscle-invasive bladder cancer by WHO 1973 and 2004 grading and by FGFR3 mutation status: a prospective study. Eur Urol 2008; 54: 835-844. http://dx.doi.org/10.1016/j. eururo.2007.12.026

[20] PLOUSSARD G, SOLIMAN H, DUBOSQ F, MERIA P, VERINE J et al. The prognostic value of FGFR3 mutational status for disease recurrence and progression depends on allelic losses at 9p22. Am J Cancer Res 2011; 1: 498-507.

[21] REBOUISSOU S, HERAULT A, LETOUZE E, NEUZILLET Y, LAPLANCHE A et al. CDKN2A homozygous deletion is associated with muscle invasion in FGFR3-mutated urothelial bladder carcinoma. J Pathol 2012; 277: 315-324. http://dx.doi. org/10.1002/path.4017

[22] VAN RHIJN B, ZUIVERLOON T, VIS A, RADVANYI F, VAN LEENDERS $G$ et al. Molecular grade (FGFR3/MIB-1) and EORTC risk scores are predictive in primary non-muscleinvasive bladder cancer. Eur Urol 2010; 58: 433-441. http:// dx.doi.org/10.1016/j.eururo.2010.05.043

[23] BAKKAR A, WALLERAND H, RADVANYI F, LAHAYE J, PISSARD S et al. FGFR3 and TP53 gene mutations define two distinct pathways in urothelial cell carcinoma of the bladder. Cancer Res 2003; 63: 8108-8112.

[23] NEUZILLET Y, PAOLETTI X, OUERHANI S, MONGIAT-ARTUS P, SOLIMAN $\mathrm{H}$ et al. A meta-analysis of the relationship between FGFR3 and TP53 mutations in bladder cancer. PLoS One 2012; 7: e48993. http://dx.doi.org/10.1371/ journal.pone.0048993

[24] LINDGREN D, LIEDBERG F, ANDERSSON A, CHEBIL G, GUDJONSSON S et al. Molecular characterization of early-stage bladder carcinomas by expression profiles, FGFR3 mutation status, and loss of 9q. Oncogene 2006; 25: 2685-2696. http://dx.doi.org/10.1038/sj.onc.1209249

[25] BALBAS-MARTINEZ C, RODRIGUEZ-PINILLA M, CASANOVA A, DOMINGUEZ O, PISANO D et al. ARID1A Alterations Are Associated with FGFR3-Wild Type, Poor-Prognosis, Urothelial Bladder Tumors. PLoS One 2013; 8: e62483. http://dx.doi.org/10.1371/journal.pone.0062483

[26] SERIZAWA R, RALFKIAER U, STEVEN K, LAM G, $S C H M I E D E L S$ et al. Integrated genetic and epigenetic analysis of bladder cancer reveals an additive diagnostic value of FGFR3 mutations and hypermethylation events. Int J Cancer 2011; 29:78-87. http://dx.doi.org/10.1002/ijc.25651

[28] TRACZYK M, BORKOWSKA E, JEDRZEJCZYK A, PIETRUSINSKI M, ROZNIECKI $M$ et al. Detection of loss of heterozygosity in patients with urinary bladder carcinoma: neoplastic tissue vs. urine sediment cells. Cent European J Urol 2011; 64: 163-167. http://dx.doi.org/10.5173/ceju.2011.03. $\underline{\operatorname{art} 16}$

[29] PAIGE A, TAYLOR K, TAYLOR C, PAUL J, MEIN C et al. WWOX: a candidate tumor suppressor gene involved in multiple tumor types. Proc Natl Acad Sci USA 2001; 98: 11417-11422. http://dx.doi.org/10.1073/pnas.191175898 
[30] BAYKARA O, DEMIRKAYA A, KAYNAK K, TANJU S, TOKER A et al. WWOX gene may contribute to progression of non-small-cell lung cancer (NSCLC). Tumour Biol 2010; 31: 315-320. http://dx.doi.org/10.1007/s13277-010-0039-3

[31] FERNANDEZ-MEDARDE A, SANTOS E. Ras in cancer and developmental diseases. Genes Cancer 2011; 2: 344-358. http://dx.doi.org/10.1177/1947601911411084
[32] BEUKERS W, HERCEGOVAC A, ZWARTHOFF E. HRAS mutations in bladder cancer at an early age and the possible association with the Costello Syndrome. Eur Hum Genet 2014; 22: 837-839. http://dx.doi.org/10.1038/ ejhg.2013.251 